plumage, although short, have been carefully drawn up and are clearly expressed, but it is not correct to say that in young greater spotted woodpeckers the "entire head is crimson," though the entire crown of the head is so. Possibly it was a slip of the pen that produced Royston's instead of Royston crow.

An important feature of the book is the bibliography-a list of books relating to British birds, brought down to I9oo. This valuable piece of work has been compiled by $\mathrm{Mr}$. W. H. Mullens for the use of those who may desire to gain some general knowledge of the work which has been done in British ornithology in the past. The final parts contain a full addenda and corrigenda to the account of rare and accidental visitors given at the end of each family, bringing the records up to date; a glossary of synonyms and provincial names of British birds, scientific and English indices, a short preface to the final volume, and the list of subscribers.

\section{DR. H. O. JONES, F.R.S.}

N Thursday, August I5, Mr. Humphrey Owen Jones, F.R.S., with his wife and a guide, met with a tragic death in an accident on the Alps, in the neighbourhood of Courmayeur, where $\mathrm{Mr}$. and Mrs. Jones were spending part of their honeymoon. They were ascending the western face of the Mont Rouge de Peuteret, and were struck by a falling rock, which had become dislodged. They fell about a thousand feet to the Fresnay Glacier. It was in an attempt to make the first ascent of a peak in the same range, the Aiguille Blanche de Peuteret, that Prof. F. M. Balfour was killed in $\mathrm{I} 882$.

Mr. Jones was born on February 20, 1878 , and was educated at the University College, Aberystwyth, and at Clare College, Cambridge. He was one of the first graduates in science of the University of Wales. He graduated at Cambridge in 1900 , obtaining the rare distinction of a "star" in chemistry in part ii. of the natural science tripos. He was admitted to the D.Sc. of the University of London in 1904. In 1902 he was appointed Jacksonian Demonstrator, a post which he held to the present time, and subsequently he became a fellow and lecturer of Clare College, Cambridge. In the present year, at the early age of thirty-four, he was elected a fellow of the Royal Society.

Mr. Jones was a man of remarkable energy and a born teacher. A peculiar quickness of perception enabled him immediately to understand and meet the difficulties of students. His lectures and his laboratory teaching, both to undergraduates and to postgraduates, were a feature of the university chemical laboratory. He was greatly interested in estimating the abilities and particular facilities of students. This characteristic made him an excellent examiner, an office which he was frequently called upon to fill, both in his own university and elsewhere. His original investigations and contributions to knowledge were numerous and many-sided. As early as 1904 he was recognised as an authority on the stereochemistry of nitrogen, on which subject he wrote a detailed critical report for the British Association, and subsequently the chapter in the annual reports of the Chemical Society. With Sir James Dewar, he investigated metallic carbonyls, and discovered carbon monosulphide. More recently he had been engaged on researches on thiooxalates, and on the intricate problem of the constitution of aldol bases.

Mr. Jones also took a very active part in affairs not purely professional. He was a co-opted member of the Cambridge Appointments Board, where his power of discriminating between candidates was of particular value, and, with others, he directed the building of the recent extension to the chemical laboratory at Cambridge. His appointment to the Royal Commission to report on the use of oil fuel in the Navy, which is just announced, would have given scope to his ability in practical problems.

It is perhaps as a mountaineer that Mr. Jones will be best known to a wide circle of friends. Finding out almost accidentally, during a visit to North Wales seven years ago, his exceptional facilities as a rock climber, he set himself to learn, with characteristic energy and directness, the highest practice of the art from the best exponents. $\mathrm{He}$ rapidly acquired a minute knowledge of the Italian side of Mont Blanc, and was the originator of several new routes. Soon becoming recognised as a skilful cragsman and experienced mountaineer, he was elected a member of the Alpine Club in I909, and was a member of the committee of the Climbers' Club.

He married, on August I, Muriel Gwendolen Edwards, the second daughter of the Rev. William Edwards, of Bangor, a member of the Edwards family to which the Bishop of St. Asaph and the late Dean of Bangor belong. Mrs. Jones was also a chemist; she was a member of Newnham College, Cambridge, and was the first woman to be elected a fellow of the University of Wales.

\section{K. J. P. O.}

\section{PROF. F. A. FOREL.}

M FRANCOIS ALPHONSE FOREL, of N. Morges, honorary professor of the University of Lausanne, who died on August 7 at seventy-one years of age, was born at Morges, on the shores of Lake Geneva, and devoted his life to the study of the lake, fostered in his studies by his father, Président Francois Forel, of Morges. "Pour nous, ses riverains," he writes, "le Léman est le roi des lacs; nous l'aimons avec enthousiasme, avec passion"; and from I868 onwards there flowed from his pen memoir after memoir dealing with "le Léman" in all its varying aspects. There is no department of limnology that he did not enrich by his researches, and he may fairly be considered the founder and chief exponent of the scientific study of lakes.

Forel's activity as an author was great. In NO. 2234, VOL. 89] 